\title{
THE SOCIAL AND SYMBOLIC POSITION OF FIGHTERS OF THE PEOPLE'S LIBERATION WAR AFTER THE LIBERATION IN THE FEDERAL PEOPLE'S REPUBLIC OF YUGOSLAVIA
}

ABSTRACT. The paper deals with the attitude of the newly formed state government in Yugoslavia, after the Second World War, towards war veterans, in the period between the enactment of the first and second constitutions of the communist Yugoslavia, the period of the Federal People's Republic of Yugoslavia (1946-1963). On the example of social protection of the fighters and their symbolic representation, especially through sculpture as the most suggestive and the most communicative medium for transmitting symbolic messages, the aim of the paper is to establish what the social position of the war veterans was in that historical period, and also to point to the important knowledge that the social protection of veterans, war invalids, as well as the families of the fallen soldiers was at an enviable level and that the new government immediately saw the importance of the symbolic representation of valuable ideals through the medium of sculpture also. In

olivera.markovic@pr.ac.rs

marta.vukotic@pr.ac.rs

Рад је примљен 16. октобра 2021, а прихваћен за објављивање на састанку Редакције Зборника одржаном 21. децембра 2021. 
the newly formed Federal People's Republic of Yugoslavia (FPRY, 1945-1963), nurturing the revolutionary tradition and the legacy of the People's Liberation War were priority social tasks.

KEYWORDS: Fighters; society; PLM; PLW; FPRY; ideology; sculpture; "the culture of rememberance".

INTRODUCTION

Yugoslavia welcomed the end of the war as a devastated country, which, thanks to an organized resistance movement, largely liberated itself. Human capital was devastated: more than 1.7 million killed, about 400,000 captured, interned and forced workers, 530,000 deported, and 320,000 forcibly recruited (Miljković, 1989). Even before the war, the industry was modestly represented, and during the war it was completely destroyed. After the new government was formally elected: the land, industry, mining, trade and banking were all nationalized and the realization of the first Five-Year Plan for Reconstruction and Industrialization of the country began.

The first post-war period is fraught with challenges, but also with the successes with which the Party, led by a charismatic leader, gained the strong favor of the broad strata. One of the greatest challenges of the post-war period was the break from the USSR, in the form of the expulsion of Yugoslavia from the Comintern and the immediate danger of the possibility of the USSR invading Yugoslavia. First a war leader, and then a state leader, Tito showed great skill and authority when he refused to obey the USSR, renewed cooperation with America (which was reflected in American military and financial assistance) and maintained a neutral position (Kačavenda, 1999). Yugoslavia built its own political, economic, and ideological order called "Yugoslav self-managing". At the same time, the country's industrialization, infrastructure construction, and constant economic growth continued. With the help of financial aid from the west, most of which was invested in industry, Yugoslavia experienced an economic miracle (Чалић, 2013, p. 242-244).

Yugoslavia was characterized by the system of a very complex bureaucratic organization, and for it all to function discipline was necessary, and the stronghold of discipline lay in the army. As Malešević (2011) puts it, "a civil servant, teacher or nurse is governed by the same principles of a bureaucratic organization that 
also governs soldiers or the police". On the other hand, that same organization offered security in a difficult time of physical destruction of the country and the time of great poverty. Therefore, it cannot be considered imposed on the will of the people. People truly adored the charismatic character of the leader of the People's Liberation Movement (hereinafter PLM), Josip Broz Tito (regardless of the fact that they may have been victims of manipulation). The broad strata approved of the actions of the new government, they perceived them as just, especially the nationalization of the country from the hated rulers.

The Federal People's Republic of Yugoslavia (hereinafter FPRY) ${ }^{1}$ emerged from its first period as the state that had sufficient bureaucratic power, as well as economic, capital, and political legitimacy to monopolize and legitimize power in the territory under its control. In exchange for legitimacy, the state expanded the economic rights of its citizens and offered social security through a policy of high employment and an egalitarian standard.

The ideological and legitimate confirmation, security, and stronghold point of the new state lay in the victory in the Second World War. The mobilized human capital for the PLM should be maintained and privileged as the most significant support for the new government. The paper aims to show how and with what forms of social protection of the former fighters, but also the families of the fallen soldiers, the newly formed government provided social care to these groups, which not only repaid the fighters for their sacrifice, but also received significant support, as well as the active agitators of the newly established government, which needed support and legitimacy. On the example of the protection of this group, the state also clearly showed the social character to which it aspired from the beginning, which made the new state immediately part of the most developed countries in the world in the field of creating a strong welfare state. In the second part, the paper deals with the symbolic representations of the victims for victory in the People's Liberation War (hereinafter PLW), and sculpture as a transmitter of messages about these sufferings, of both survivors and all future generations, to continue their struggle in peace.

1 After the elections for the Constituent Assembly in November 1945, on $29^{\text {th }}$ November 1945 the state was renamed from the original Democratic Federal Yugoslavia (DFY) into Federal People's Republic of Yugoslavia (FPRY), which changed the name into Socialist Federal Republic of Yugoslavia (SFRY) in 1963. 
LEGAL AND SOCIAL PROTECTION OF VETERANS AND FAMILIES OF FALLEN FIGHTERS AFTER 1945

Establishing, foundation and ideological legitimacy of the new government was based on the victory, that is, the liberation of the country won by the participants in the war led by the supreme commander and leader, Tito. This significant human capital had to be maintained by a large number and by strength. "The regime in the Federal People's Republic of Yugoslavia needed the favor of a large group of wounded invalids and families of killed, dead and missing soldiers (about 400,000 people with numerous family members, which, in total, was undoubtedly above a million people), so, it tried to provide them with social protection efficiently" (Маловић, 2011a, p. 386). To hint at its social character ${ }^{1}$, immediately after the end of the war, the new government set to work on the social care of the most vulnerable categories of the veteran population, such as the disabled, the families of the fallen, the missing and the dead, and then the fighters themselves. In the conditions of great destruction of the country, illiterate and semi-literate rural population, great efforts had to be made in order to find funds and create conditions to alleviate the suffering of these social groups. Thus, for example, 283,252 war orphans without one or both parents had to be taken care of (Петровић Тодосијевић, 2007, p. 105). As health conditions and social protection were at an extremely low level, the priority of the new authorities was to remedy this situation. One of the successes was the suppression of widespread infectious diseases until the first half of the fifties, with the help of UNICEF and the World Health Organization. ${ }^{2}$ That the health conditions were at a low level was also shown by the data on the high mortality rate, that is that the average human age in Yugoslavia, being 50.89 years in 1953, but differences between the republics were very drastic (Петровић Тодосијевић, 2007, р. 105).

That the special care of the wounded fighters would be taken by the new government was announced by Tito (as the supreme commander and the Minister of the Military Administration) in 1945 during the visit to the II command hospital in Zagreb (Маловић, 20116). Even before the formal legal provisions were enacted in the form of laws ${ }^{3}$, the new government got to work on enumeration of

\footnotetext{
1 "Democratic rights are according to him (Tito) must be subordinated to the axiom of social justice", Čalić, 2013, p. 239.

2 Петровић Тодосијевић, 2007, р. 104
} 
all persons to gain the fighters status or the status of families of the fallen fighters, and also the first one-time financial assistance for the persons that were not able to aquire all the necessary documents or were unable to create conditions for recognition of this status was provided (Vukotić Lazar \& Marković-Savić, 2020). This way of financial help was subsequently transformed by law into regular monthly income to these population categories. The new government did not forget neither veterans nor war invalids from the previous wars (war invalids from the previous wars of Serbia and Montenegro 1912-1918, war invalids from the Kingdom of Yugoslavia from the April 1941 war) under the condition that they did not participate on the side of the enemy armies.

After the extensive work of the registration was brought to an end in October 1948, in total, 82,258 personal invalids and 210,892 family invalids were recognized ${ }^{1}$ (Маловић, 2011a). It should be emphasized that the making of such register was a huge undertaking in conditions of the lack of evidence and illiterate population ${ }^{2}$ and as such was brought to an end in just a few years.

The invalids were entitled to health protection (including spas and convalescent homes), professional training and retraining, to employment (as early as in 1947, 29,000 invalids were employed). Even after the transition under the civil administration, that is, in jurisdiction of the Committee for Social Care in November 1948, the fighters of PLW maintained their priviledged social status in the society (in relation to, for example civil war invalids) and it was known that they enjoyed special affection of the Supreme Commander (Маловић, 20116).

The period of the transition under the so-called civil authority is characterised by the foundation of Alliance of Veterans of the People's Liberation War (Serb: Savez boraca Narodnooslobodilačkog rata, hereinafter SUBNOR) of Yugoslavia at the First Congress of the Fighters of PLW held in September 1947 in Belgrade. In the following year, 1948, republic and provincial committees of SUBNOR ${ }^{3}$

\footnotetext{
Passed on May $25^{\text {th }} 1946$

After the revision, 3207 invalids, around $20 \%$ lost this status

The job of enumeration did not go smoothly, people's committees were not interested in finishing the job efficiently and promptly, having in mnd that they did not consider this to be under their jurisdiction but the Ministry of Defense under whose jurisdiction were the fighters' population matters. Because of the slow progress, invalid officer was introduced at each provincial committee with the military status (Маловић, 20116).
} 
were formed, and in 1961 there was the merge with the The Alliance of War Invalids and the Association of Reserve Officers and Non-Commissioned Officers and the organization operated under the name of SUBNOR. The organization had a sociopolitical character and the membership was voluntarily, consisted of former fighters and assosiates of PLW. At the very beginning, the membership was limited to "fighters in arms" but in time it was realized that it had been too narrow a category which needed to be broadened and thus the formulation was formed "participant in PLW" (Graovac, 1974), the membership of the SUBNOR was about a million persons.

All forms of work and action were aligned with the program of the League of Communists of Yugoslavia and the program principles of the Socialist Alliance of Working People of Yugoslavia ${ }^{2}$. The Alliance performed diverse activities in its work: from keeping records and personnel policy, through socio-economic and social issues and care for the fighters and the families of the fallen fighters up to nurturing and developing PLW traditions and revolution legacy. After the Alliance of War Veterans had become the integral part of the SUBNOR, the board that monitored the regulations of the protection of the invalids, suggested changes and amendments for improvement of the financial and health status of the war invalids (Jukić, 2006). Having in mind that members of the Alliance, apart from the fighters, could also be persons who had actively helped PLW, as well as the capruted activists who remained at the front line of the PLW despite the torture, interns or the persons in forced labor due to helping the PLW, as well as those who fought against fascism within some other resistance movement (Spanish, French, and others), there were boards that gathered the data on suffering in prisons and concentration camps both in the country and abroad, and thus gave opinions in determining the spacial status. Then, there was a board that dealt with the children of the fall-

3 "In accordance with the state territorial-administrative arrangement, veteran organizations formed in the area of local, town and provincial people's committees and then district people's committees up until their abolition in 1951" (Filipović, 2021, p. 46)

1 "Not a bit less interesting were those results which contained the division of participants in the People's Liberation Movement, especially because they show that in both PLW and allied armies only 50,5\% participants from the total number of participants took part in, which once again demonstrates that the definition of participants "people in arms" was irregular and too narrow." Graovac, p. 37

2 The Statute of SUBNOR, stated according to Jukić (2006) 
en fighters, gathered data on them, placed them in students' homes or in foster families, cared about their education as well as organized their summer holidays, and finally, provided them employment. The Aliance certainly took care of the social problems of the fighters, such as veterans' pension, collective insurance, special veterans' cash allowance, health protection, construction and distribution of apartments to the fighters and invalids, their medical treatment, education and employment of the fighters and their children. All this made the care of the fighters be comprehensive and on a very high level (Марковић-Савић, 2016, p. 325).

A very important part of the SUBNOR was the keeping and spreading specific memories of the war. For that purpose, the SUBNOR made decisions and managed museums, chronicles, naming the streets and towns, but the most important task was the erection and arrangement of monuments as well as arrangement of tombs to the fallen fighters. Monuments to the dead, that is, killed for the idea, fame and thanks were especially important ideological segment in legitimation of the new government, and together with the care for the veterans made a complex of ideological strengthening, presentation and preservation of the system. The fighters of the PLW gained the political authority upon the building of the new society and the system on the wings of victory, and, as such, they were the key of the legitimation of the new government during the postwar period. One of the important traits of the PLW and the Yugoslav army was multiethnicity, which was of high importance in promoting the policy of "brotherhood and unity" of the people and nationalities of the federation then.

Especially strong form of legitimation came from Tito's charismatic authority; the one who was perceived as a great revolutionary who successfully led the People's Liberation Movement up until the final victory over the enemy. Apart from being the party and state leader, Tito was the most important war hero.

Amongst the myths, symbols and rituals, certainly the most outstanding were partisan and other symbols from the partisan fight in which all Yugoslav people participated and upon which the main legitimation of the Communist party and its lifelong and inviolable leader Tito was based. The cult of Tito's personality was conceived as early as during the PLW and the revolution, with great and growing support of the people, more and more loyal and professional military force, and greater reputation that his guerrilla fight had been gaining, as well as the image of the anti-fascist fighter. Since 
then, carefully at first, and later more and more determined, the policy led by him distanced itself from the Soviet patronage which treated the Communist Party of Yugoslavia as its puppet branch.

Changes in international relations affected the internal political and economic circumstances so that in January 1953 the Constitutional law on the basics of social and political arrangements and federal authority was passed, modified Constitution from 1946, with the aim of decentralization of political power. State property was still under the rule of the Communist (Socialist) party, and the changes were in names only, where governments became executive committees, and ministries secretariates. Instead of the function of supreme commander, marshal Tito became the president of the Republic, but remained on the function of the party secretary and the Prime Minister, by which war dictatorship ended in Yugoslavia. (Donkić, 2013, p. 110, 227-258)

REVOLUTIONARY SCULPTURE AS A CARRIER OF A POLITICAL-ARTISTIC PRACTICE

Sculpture on a symbolical level became a mechanism for implementation of an official version of the past and a new identity, contributing to the transformation of public areas, but also to transformation of the natural into historical memory (Asman, 2011, p. 311; Вукотић Лазар, 2015, р. 280; Вукотић Лазар \& Даниловић Христић, 2012 р. 290). It faced numerous changes regarding the domain of the thematic design, thus, as unavoidable, there were the main themes: memories of the horrors of the war, suffering of the Partisans and Yugoslav people, glorification of CPY, etc.

Unlike graphics, drawings or paintings - the sculpture withing the period 1941-1945 did not have continuous full development, except in the work of the sculptor Antun Avgustinčić who as early as during the war carved the Tito's bust, and then, by Tito's order, he was sent to Monopoli (Bari district, Apulia) to make medals for the partisan army. On that occasion, he made the sketches for the following medals: Order of the People's Hero, Order of the Partisan Star (first, second and third class), Order of the Brotherhood and Unity, and Medal for Bravery (Filips, 1983, p. 50). The new government immediately after the liberation recognized the sculpture as the most suggestive and the most communicative medium for transmission of its political messages (Стојановић, 1955, p. 461-475). 


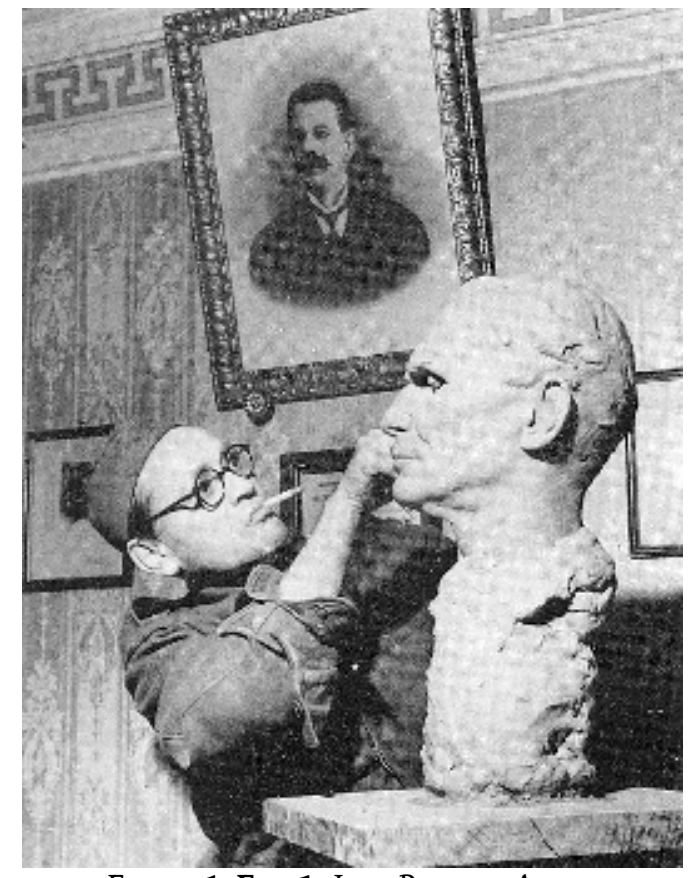

FigURE 1: FIG. 1. JOHN PHILLIPS, ANTUN AVGUSTINČIĆ IS SCULPING TITO'S BUST IN JAJCE BEFORE THE SECOND CONVENTION OF THE AVNOJ IN NOVEMBER 1943.

The new ideology treated the sculpture as a social weapon with which all that had come from the previous period should be denied and messages of the new "partisan art" whose purpose is to impose itself upon the broad masses of people as the moral and ideological foundation of the one-party system should be conveyed. The main work method insisted upon was based on a more realistic, more recognizable and clearer representation, and what was the most important, the message resulted from it must go to the right place and be understood by all layers of the masses of the whole Yugoslavia. As the most purposeful medium for this way of communication and for announcements of great themes from the PLW with no doubt were public monuments, which as political symbols in the space and time from the very beginning had the task to also memorise and represent the collective memory (Protić, 1982, p. 78).

Throughout the whole Yugoslavia the monuments were being erected, monuments glorifying the revolution and the PLW, as well as ossuaries to the fallen fighters, victims of the war and the revolu- 


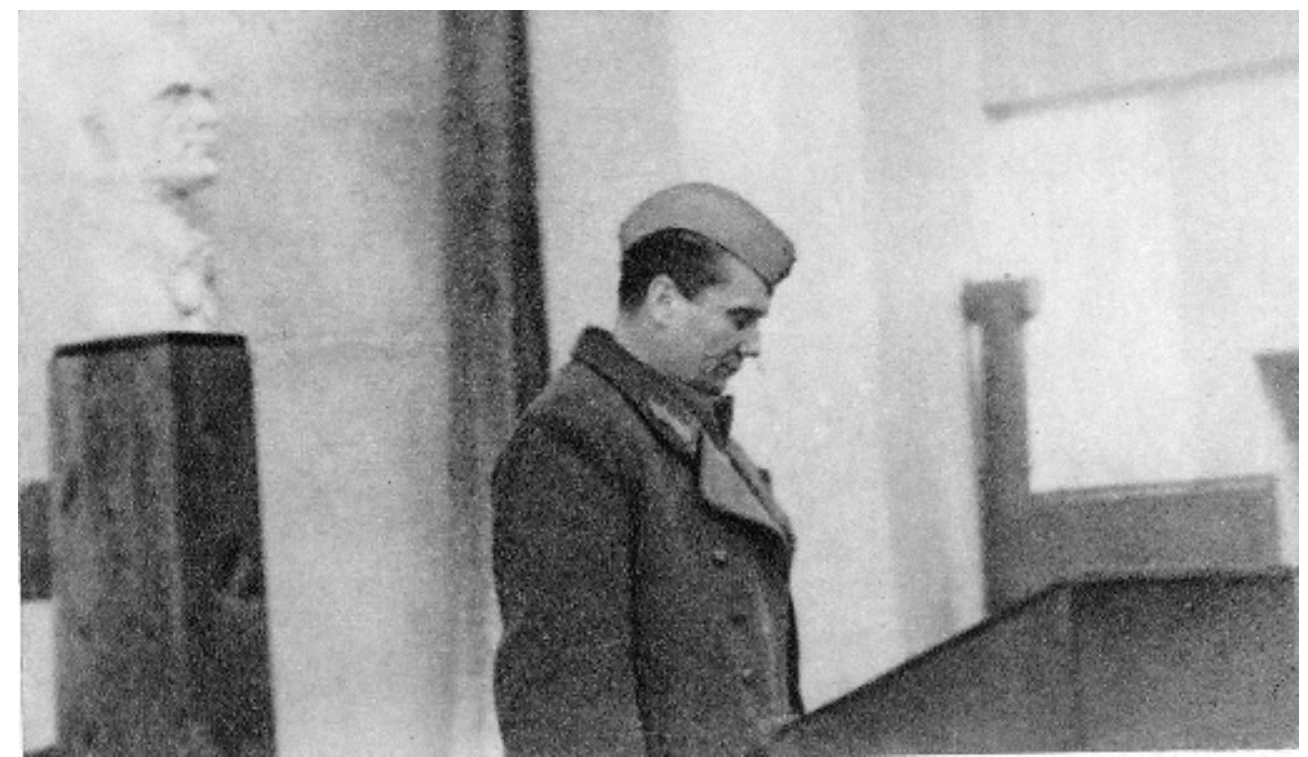

FigURE 2: Fig. 2. THE SUPREME COMMANDER JOSIP BROZ TITO SUBMITTING THE REPORT ON THE DEVELOPMENT OF THE PEOPLE'S LIBERATION WAR AT THE SECOND SESSION OF THE AVNOJ IN JAJCE IN 1943. BEHIND HIM, TITO'S BUST, THE WORK OF AVGUSTINČIĆ CAN BE SEEN.

tion. This was about the figural compositions of the narrative form, where often in an allegorical way in stone or bronze, heroic fight and the suffering of the fighters were depicted, mass scenes or single figures in an action, where characters were heroized, and the events immediately recognizable.

The ideal of a new man and the new society had their stronghold in the cult of personality of Josip Broz Tito. Originated in the PLM, Tito's cult was nevertheless in the Stalin's shadow (as a small reflection as suggested by Phillips' photo from 1943 where Avgustinčić was sculpting Tito's bust while in the background there is Stalin's photo on the wall). Main streets and representative squares in almost every city and town in former Yugoslavia had Tito's name (Радовић, 2014, p. 101-125; Merenik, 2001). Four cities were even named after Tito during his life, them being: Tito's Korenica, Lika, Croatia (1945), Tito's Užice, Serbia (1946), Titograd, Montenegro (1946) and Tito's Veles, (North) Macedonia (1946), while Tito's Velenje, Slovenia (1981), Tito's Drvar, Bosnia and Herzegovina (1981), Tito's Mitrovica, AP Kosovo and Metohija, Serbia, (1981) and Tito's Vrbas, AP Vojvodina, (1983) were named after Tito after his death (Radović, 2013, p. 62-80). 


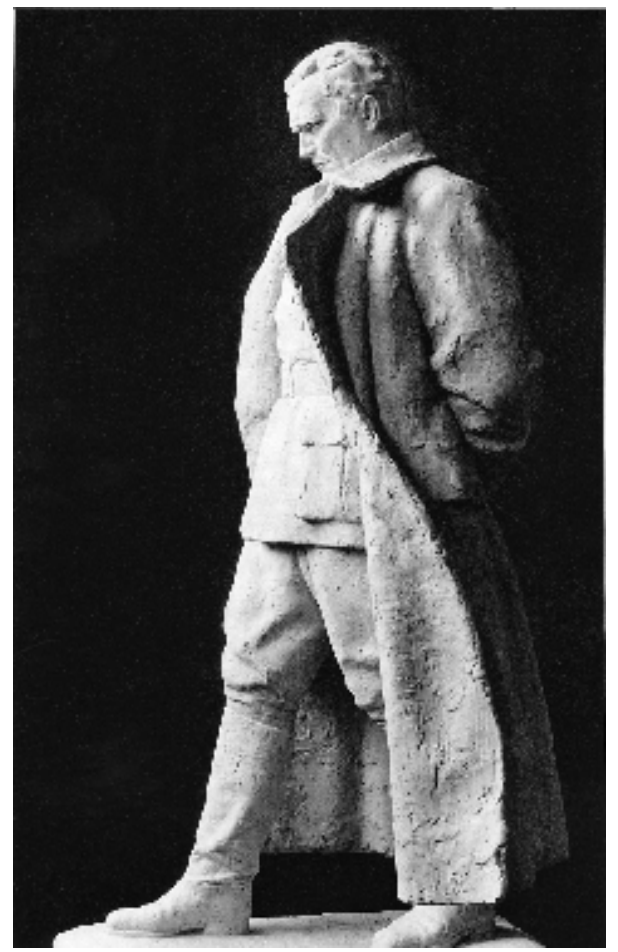

FIGURE 3: Fig. 3. ANTUN AVGUSTINČIĆ,

THE MONUMENT OF MARSHAL TITO, KUMROVEC, 1947-1948.

The first Monument of Marshal Tito was solemnly unveiled in 1948 in his birthplace Kumrovec in Croatia and it is the work of Antun Avgustinčić (Baldani, 1977, p. 50). The putting up of this monument symbolically signified a break up with the first period of social realism in art (1945-1948), which glorified the unity with the USSR and Stalin's cult and where the Soviet ideals were strong in all domains, thus, in the domain of fine Arts. (Dedijer, 1955, p. 403-443; Čavoški, $1990,13-21)^{1}$

After 1948 until the beginning of the 1970, the establishment of the Yugoslav identity itself began by remembering the narrative of the PLW and the great revolution. Social realist stereotypes continued to live on, but now through glorifying the PLW, revolution and

1 The replica of the Monument of Marshal Tito was placed in 1977 on the main city square, then bearing the name of Tito's square in Velenje in Slovenia, since 1981 in Tito's Velenje, 1981. (Baldani, 1977, p. 188) 
partisan fight with no glorification of the Red Army. Since 1948, partisans, fallen fighters and civilians, Yugoslav war and revolution victims were paid tribute (Cvetić, 2012, p. 307).

In Užice, as the centre of the great liberated territory in Serbia by the end of 1941, the first partisan weapon factory was working, magazine Borba and the bulletin of the Supreme staff were printed, the first National Liberation Committee (Serb: Narodnooslobodilački odbor Srbije, hereinafter NOOS) was founded, and there was the Supreme Headquarters situated during the October and November. All this led to the decision to transform the city of Užice into a memorial city. The first step regarding this decision was announcing the competition for creating an urban plan for the centre of Užice in 1953. Not until 1957 was the making of the urban plan awarded by the People's Committee to the architect Stanko Mandić, and the Partisan Square was finished in 1961 by his layout (Ilić, 1953, p. 119-124; Milenković, 1962, p. 4-10; Đokić, 2009, p. 213-223).

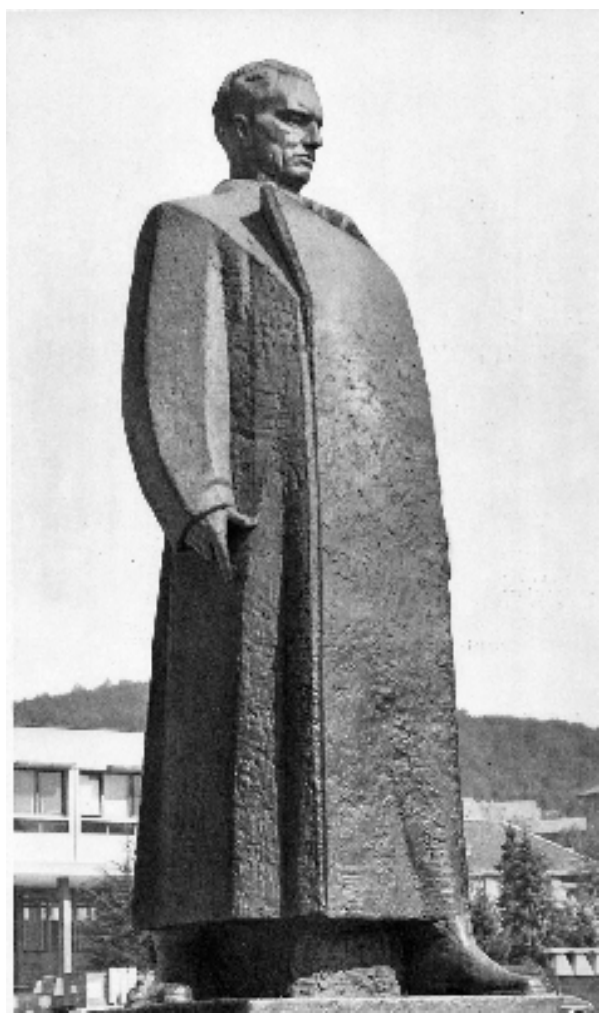

FigURE 4: FIG. 4. FRANO KRŠINIĆ, THE

MONUMENT OF MARSHAL TITO, TITO'S

UŽICE, 1962. 
On the occasion of fifteen years since renaming of the city into Tito's Užice, and, on the twentieth anniversary since the uprising in Serbia, on the main city Partisan square, the Monument of Marshal Tito was erected in 1962, the work of Frano Kršinić, who, as early as 1949, also created a sketch for the monument Marshal Tito on a Horse, intended for Zagreb but which was never realised (Baldani, 1977, p. 55).

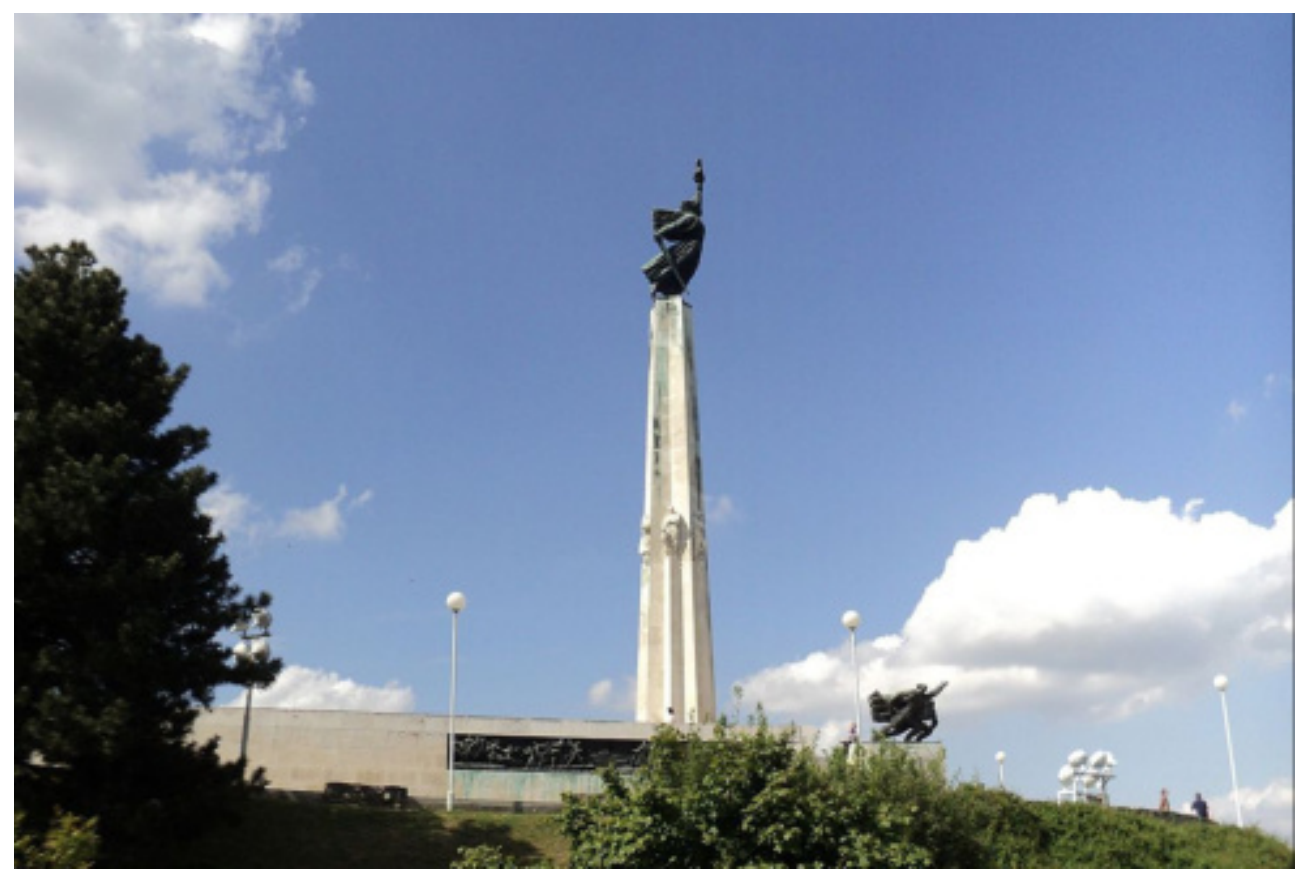

FiguRe 5: Fig. 5. ANTUN AVGUSTINČÍć, THE MONUMENT OF GRATITUDE TO THE RED ARMY, BATINA, 1945-47.

One of the first monuments of the PLW in Yugoslavia was The Monument of Gratitude to the Red Army, on Batina, (1945-1947), the work of Antun Avgustinčić, which symbolizes the encounter of Yugoslav Partisan Units and the Red Army at the Batina ferry on the Danube. On the stone pedestal of $35 \mathrm{~m}$ a bronze sculpture of Victory $8 \mathrm{~m}$ high was set, and at the foot of the bronze sculpture, there were two relieves set depicting fighters. In the middle of the stone pillar there were 5 stone figures set symbolizing different military ranks.

As early as 1944, Antun Avgustinčić made a concept for Red Army Soldier Monument erected at the Cemetery of the Liberators of Bel- 
IGURE 6: Fig. 6. ANTUN AVGUSTINČIĆ, MEMORIAL CEMETERY OF THE LIBERATORS OF BELGRADE, 20TH OCTOBER 1954.

grade on the occasion of 10 years from liberation of Belgrade, on the 20th October 1954. This is the first memorial complex done in Belgrade after the Second World War. The memorial cemetery is dedicated to Yugoslav and Soviet fighters killed in the battles for the liberation of Belgrade in October 1944. 1395 PLW and POJ (in Serbian POJ being Partizanski Odredi Yugoslavije, Partisan Detachments of Yugoslavia) fighters along with 818 fighters of the Red Army were buried here..$^{1}$ (Мирјанић, 1955, p. 511) The cemetery was built according to the project of the architect Branko Bon and

1 In direct fighting for the liberation of Belgrade, the First Army group of the Yugoslav Partisans (hereinafter NOVJ) had 2953 killed and over 3000 wounded fighters, while the Soviet forces had 961 killed and undetermined number of wounded. In the centre of Belgrade itself, on the $22^{\text {nd }}$ of October 1944, today's Republic Square, alongside the monument of Prince Mihailo, the remains of the Red Army fighters were solemnly buried during the Belgrade Offensive; on this occasion, general Ždanov addressed the people. In the following couple of months after this event, in the centre of Belgrade at almost all significant squares, the tombs for the Red Army fighters were settled. From $15^{\text {th }}$ until $30^{\text {th }}$ November 1944, residents of the capital erected 18 great and 32 smaller monuments; additionally, 52 small monuments were prepared for the setting up until $10^{\text {th }}$ December. All of these monuments were removed in the beginning of the fifties of the $20^{\text {th }}$ century, and the remains were relocated to Liberators of Belgrade Memorial Park, which was ceremoniously opened on the $20^{\text {th }}$ October 1954. (Лазић, 2014, p. 20) 
the horticultural engineer Aleksandar Krstić, and the sculptor Radeta Stanković created the relieves on the monumental entrance gate.
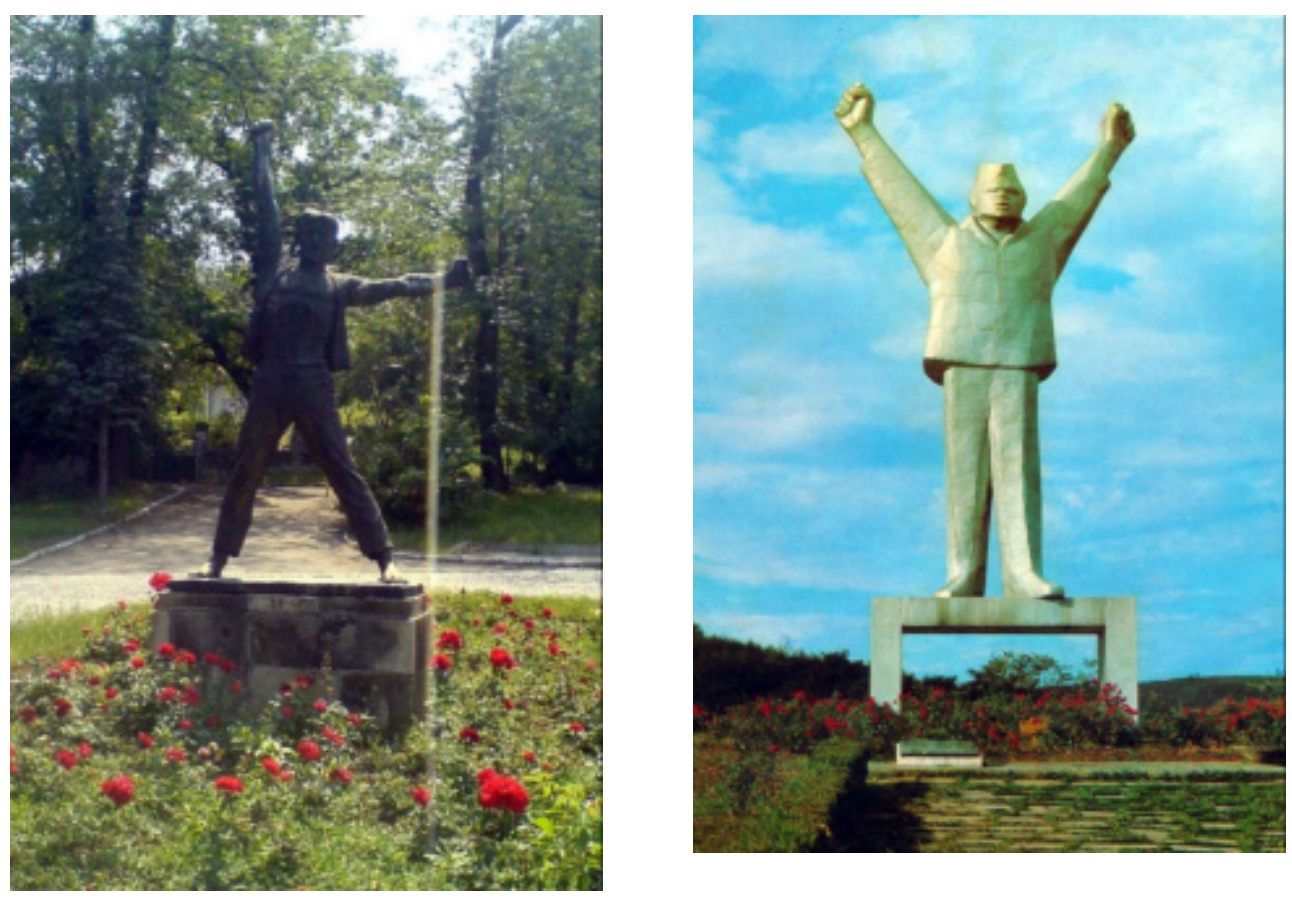

FiguRE 7: Fig. 7. VOJIN BAKIĆ, A CALL FORA N UPRISING, BELGRADE, 1946-47 AND THE MONUMENT OF STEVAN FILIPOVIĆ, VALJEVO, 1960.

CONCLUSION The new government of the socialist federation legitimized itself based on the participation and the victory in the Second World War. The memory of the PLW and the killed fighters was the ideological platform (that is, operative ideology and educational symbolism), and the alive and useful participants were a part of the social organization. This way, the latent state of war continued; the new government had a lot of enemies, starting from local (counter-revolution, remains of the former system, sympathizers of the monarchy, national elite) up to global (break with USSS, capitalism from the West). There, the rule should be established and maintained over the whole territory, and broadly a whole new system should be built. 


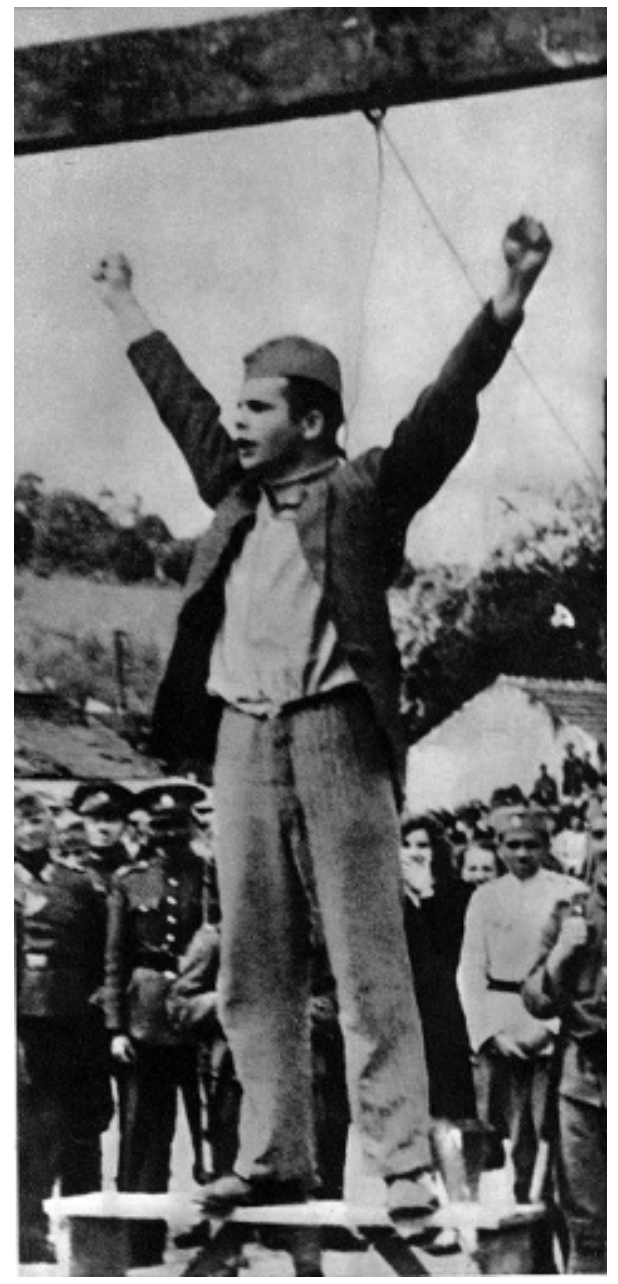

FigURE 8: Fig. 8. NATIONAL HERO STEVAN

FILIPOVIĆ IN VALJEVO ON THE 22ND MAY 1942

FROM THE GALLOWS CALLS ON THE PEOPLE TO

FIGHT AGAINST THE OCCUPIERS AND DOMESTIC

TRAITORS

In such conditions, the creators of the policy took serious care to organize and conduct the mass acknowledgement of the status of the fighters and the families of the killed, died and disappeared which to all recognized categories brought social protection but also socially symbolic power. Legal protection of the fighters, war invalids and the families of the fallen fighters in the period after the Second World War is a very significant period for studying legal protection and the overall position of the war veterans in the Yugoslavia then. Concretization of the legally guaranteed measures and state aid to the above mentioned groups, but also the realization of the prescribed norms were on a remarkable level. There were two dominant reasons for this: firstly, the new government legitimized 
itself through these social groups, and secondly, there was an intention to arrange the state upon the principles of a welfare state. For the social position of the fighters of great importance was the forming of the roof organization which took the leading role not only in caring about the survived fighters, but also about starting initiatives, organizations and implementation of the active memory of the PLW.

The new government led by the lifelong president of the SFRY Josip Broz Tito immediately recognized art as an important and equal factor of the social political fight for achieving the goals of socialism, and the sculpture as the most suggestive and the most communicative medium for transmitting its political messages. Almost all sculptors from the territory of the former Yugoslavia were mobilized for the construction of the realistic monuments, legible and clear in form and with the aim to become educational tool intended to the masses and with the function of realizing the vision of the new society.

Asman, J. (2011). Kultura pamćenja: pismo, sećanja i politički identitet u ranim visokim kulturama. Beograd: Prosveta.

Baldani, J. (1977). Revolucionarno kiparstvo. Zagreb: Spektar.

Čavoški, K. (1991). TITO - Tehnologija vlasti. Beograd: AIZ Dosije.

Cvetić, M. (2021). Monumentalna memorijalna politička skulptura. U: M. Šuvaković (prir. i ur.), Istorija umetnosti u srbiji XX veka. Realizmi i modernizmi oko hladnog rata, drugi tom (303-322). Beograd: Orion Art.

Dedijer, V. (1955). Josip Broz Tito. Prilozi za biografiju. Beograd: Kultura.

Đokić, V. (2009). Urbana tipologija: gradski trg u Srbiji. Beograd: Univerzitet u Beogradu, Arhitektonski fakultet.

Doknić, B. (2013). Kulturna politika Jugoslavije (1946-1963).Beograd: Službeni glasnik.

Filips, Dž. (1983). Jugoslovenska priča (1943-1983). Beograd-Zagreb: Jugoslovenska revija - Mladost.

Ilić, R. (1953), Titovo Užice. U: M. Mitorivić (ur.), Gradovi i naselja u Srbiji, razvoj, urbanistički planovi i izgradnja 1946-1961 (119-125). Beograd: Urbanistički zavod NR Srbije.

Jukić, M. (2006). Prilog poznavanju ustanova: Savez udruženja boraca Narodnooslobodilačkog rata Hrvatske (1947-1992). Arhivski vjesnik, 49 (1), 123138.

Kačavenda, P. (ur.). (1999). Jugoslovensko-sovjetski sukob 1948. godine: zbornik radova sa naučnog skupa. Institut za savremenu istoriju. 
Malešević, S. (2011) Sociologija vojske i rata. Zagreb: Jesenski i Turk.

Merenik, L. (2001). Ideološki modeli: srpsko slikarstvo 1945-1968. Beograd: Beopolis, Remont.

Milenković, B. (1962). Trg Partizana u Titovom Užicu, Arhitektura urbaniazam, 13, 4-10.

Miljković, D. (Ed.). (1989). Jugoslavija 1918-1988: statistički godišnjak. Savezni zavod za statistiku.

Маловић, Г. (2011а) Реферат о војној надлежности над ратним војним инвалидима у Југославији 1945-1948. Гласник Удружења архивских радника Републике српске, 3, 385-412.

Protić, M. (1982). Skulptura XX veka. U: N. Tanasijević-Popović (ur.), Umetnost na tlu Jugoslavije (19-138). Beograd-Zagreb-Mostar: Izdavački zavod Jugoslavija - Spektar - Prva književna komuna.

Radović, S. (2013). Grad kao tekst. Beograd: Biblioteka XX vek.

Vukotić Lazar M. i Marković Savić, O. (2020). Cultural policy and memory of the fighters of the people's liberation war: the central role of the army in political legitimation of the new political structure. Zbornik radova Filozofskog fakulteta u Prištini, 50 (3), 27-44.

Вукотић Лазар, М. (2015). Уметност у јавном политичком простору у контексту „отворене позорнице“: Трг Славија у Београду и споменик Димитрију Туцовићу. У: П. Миленковић, С. Стојшин, А. Пајванчић-Ци-

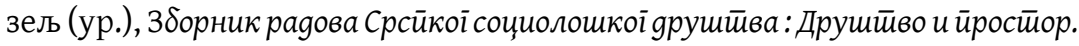


299). Нови Сад: Српско социолошко друштво.

Вукотић Лазар, М. и Даниловић Христић, Н. (2012). Значај савремене уметности у процесу интердисциплинарног дизајна јавног градског

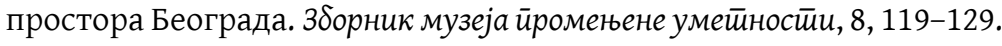

Лазић, С. (2014). Ослобођење Београда 70 година после кроз фондове и збирке Историјског архива Београда: каталог изложбе. У: С. Лазић (аутор изложбе и каталога), Ослобођење Беоіраga 70 іоgина йосле кроз фонgове и збирке Исӣоријскої архива Беоіраgа (9-69). Београд: Историјски архив Београда.

Маловић, Г. (2011ठ). Војна надлежност над ратним бојним инвалидима у Југославији 1945-1948. Војно-исӣоријски іласник, 1, 114-144.

Марковић-Савић О. (2016). Преглед социјалне историје ислужених ратника у Србији, У: У. Шуваковић (ур.), Век срӣске їлійе̄e (1915-2015) (307330). Косовска Митровица: Филозофски факултет Универзитета у Приштини.

Мирјанић, Б. (1955). Прослава десетогодишњице ослобођења Београда. Гоgишњак музеја іраgа Беоіраgа, II, 551-530. 
Петровић Тодосијевић, С. (2007). (Дис)континуитет ठез преседана: здравствена политика југословенске државе у првој половини 20. века. Токови истиорије, 3.

Радовић, С. (2014). Беоіраgски оgоними. Београд: Етнографски институт САНУ.

Стојановић, Б. (1955). О споменицима Београда. Гоgишњак музеја іраgа Бeoipaga, II, 461-475.

Чалић, М-Ж. (2013). Ист̄орија Jуіоолавије у 20. веку. Београд: Clio.

LIST OF ILLUSTRATIONS:
Figure 1. John Phillips, Antun Avgustinčić is sculping Tito's bust in Jajce before the Second Convention of the AVNOJ in November 1943.

Figure 2. The supreme commander Josip Broz Tito submitting the report on the development of the People's Liberation War at the Second session of the AVNOJ in Jajce in 1943. Behind him, Tito's bust, the work of Avgustinčić can be seen.

Figure 3. Antun Avgustinčić, The Monument of Marshal Tito, Kumrovec, 1947-1948.

Figure 4. Frano Kršinić, The Monument of Marshal Tito, Tito's Užice, 1962.

Figure 5. Antun Avgustinčić, The Monument of Gratitute to the Red Army, Batina, 1945-47.

Picture 6. Antun Avgustinčić, Memorial Cemetery of the Liberators of Belgrade, 20th October 1954. (Liberators of Belgrade Memorial Park)

Figure 7. Vojin Bakic, A Call for an Uprising, Belgrade, 1946-47 and The Monument of Stevan Filipović, Valjevo, 1960

Figure 8. National Hero Stevan Filipović in Valjevo on the 22nd May 1942 from the gallows calls on the pople to fight against the occupiers and domestic traitors 


\section{ОЛИВЕРА С. МАРКОВИТ САВИЋ}

УНИВЕРЗИТЕТ У ПРИШТИНИ СА ПРИВРЕМЕНИМ СЕДИШТЕМ У КОСОВСКОЈ МИТРОВИЦИ, ФИЛОЗОФСКИ ФАКУЛТЕТ КАТЕДРА ЗА СОЦИОЛОГИЈУ

МАРТА М. ВУКОТИЋ ЛАЗАР

УНИВЕРЗИТЕТ У ПРИШТИНИ СА ПРИВРЕМЕНИМ СЕДИШТЕМ У КОСОВСКОЈ МИТРОВИЦИ, ФИЛОЗОФСКИ ФАКУЛТЕТ КАТЕДРА ЗА ИСТОРИЈУ УМЕТНОСТИ

\section{РЕЗИМЕ}

ДРУШТВЕНИ И СИМБОЛИЧКИ ПОЛОЖАЈ БОРАЦА НАРОДНООСЛОБОДИЛАЧКОГ РАТА НАКОН ОСЛОБОЪЕЊА У ФЕДЕРАТИВНОЈ НАРОДНОЈ РЕПУБЛИЦИ ЈУГОСЛАВИЈИ

Рад се ठави односом новоформиране државне власти у Југославији након Другог светског рата према ратним ветеранима, у периоду између доношења првог и другог устава комунистичке Југославије, периодом Федеративне Народне Републике Југославије (1946-1963). На примеру социјалне заштите бораца, те на основу симболичке представе ठораца, посебно кроз скулптуру као најсугестивнији и најкомуникативнији медиј за преношење симболичких порука, циљ рада је да да̂ одговор на питање какав је ठио друштвени положај ратних ветерана у том историјском периоду, као и да укаже на важно сазнање да је социјална заштита бораца, ратних инвалида, као и породица палих ठораца, била на завидном нивоу и да је нова власт одмах увидела значај симболичке представе вредносних идеала и кроз медиј скулптуре. У новоформираној Федеративној Народној Републици Југославији (ФНРЈ, 1945-1963) неговање револуционарне традиције и текови Народноослободилачког рата ठили су, приоритетни друштвени задаци.

КљУчнЕ РЕчи: борци; друштво; НОР; НОБ; ФНРЈ; идеологија; скулптура; „култура памћења“.

Овај чланак је објављен и дистрибуира се под лиценцом Creative Commons Ауторство-Некомерцијално Међународна 4.0 (CC BY-NC 4.0 |

https://creativecommons.org/licenses/by-nc/4.0/).

This paper is published and distributed under the terms and conditions of the Creative Commons Attribution-NonCommercial International 4.0 licence (CC BY-NC 4.0 | https://creativecommons.org/licenses/by-nc/4.0/). 